\title{
English as a "Killer Language"? \\ Multilingual Education in an Indigenous Primary \\ Classroom in Northwestern Mexico
}

\author{
María Rebeca Gutiérrez Estrada (Corresponding author) \\ Department of Foreign Languages, University of Sonora \\ Dr. Noriega and Galeana, Col. Centro, Hermosillo, Sonora, Mexico \\ Tel: 011-52-(662)-213-93-31Ｅ-mail: gutierrezrebeca@lenext.uson.mx
}

\author{
Sandra R. Schecter \\ Faculty of Education, York University \\ 4700 Keele Street, Toronto, Ontario M3J 1P3, Canada
}

Tel: 1-416-736-2100 ext. $30730 \quad$ E-mail: SSchecter@edu.yorku.ca

Received: March 18, 2018 Accepted: May 17, 2018 Published: May 29, 2018

doi:10.5296/jei.v4i1.12849 URL: https://doi.org/10.5296/jei.v4i1.12849

\begin{abstract}
We report findings of an ethnographic study that explored complexities of English Language Teaching (ELT) in a minority indigenous context in northwestern Mexico. The study investigated a trilingual education setting at the nexus of 2 major events: incorporation of Intercultural Bilingual Education throughout Mexico and integration of ELT into the country's public school system. Methods included participant observation in primary-level language classes and semi-structured interviews with educators and other stakeholders affiliated with a rural school where an indigenous variety, a societal variety, and a foreign language were taught. Findings indicate that teacher agency was a powerful tool in linguistic and cultural maintenance and transforming language policy and planning at the local level. Although the spread of English may be unavoidable, with local community involvement and a school-based commitment to support linguistic and cultural maintenance, the micro language policy context can be configured to promote a symbiotic relationship among linguistic varieties.
\end{abstract}


Keywords: Multilingual education, Indigenous languages, ELT, Additive/subtractive bilingualism, Teacher agency

\section{Introduction}

This article discusses ethnographic findings of a multidisciplinary, mixed-methods study that sought to explore the intersection of Intercultural Bilingual Education policy and English Language Teaching (ELT) in a minority linguistic context in Mexico. The larger study examined the impact of changes in language policy and the introduction of ELT in a minority indigenous language context in the Mayo Region of northwestern Mexico. In this paper we focus on the study's findings related to meanings that bilingual or multilingual status held for individuals and within the community (cf. Schecter, 2015; Schecter \& Bayley, 2002) and the ways in which these identity-infused meanings connected to local conditions, including the agentive practices of professional educators.

We begin with a discussion of theoretical frameworks and research precedents that are regarded as seminal in the field of multilingual education and undergird language and language-of-education policy in settings such as the one presented here. Next, we elaborate on the macro context for multilingual education within indigenous communities in the Mayo Region, that is, the sociolinguistic landscape and infrastructural context related to language policy in Mexico. We then describe the methodology used to carry out the ethnographic inquiry for this study, present our research findings, and, finally, discuss the theoretical and applied implications of our work.

\section{Theoretical Frameworks and Research Precedents}

Our interest in carrying out the original project (cf. Gutiérrez Estrada, 2015) was spurred by the current educational policy environment in Mexico that places a state-funded English language teaching program at the core of educational processes promoting linguistic and cultural maintenance within the country's indigenous communities. Our expectations were influenced by the theorizing of relationships between dominant and subordinate language varieties within applied linguistics circles, and by interpretations of findings of research studies on language acquisition, retention, and loss within sociolinguistic contexts where more than one language plays a significant role (e.g., Gaudet \& Clément, 2005; Louis \& Taylor, 2001). In this light, we had reason to anticipate that the indigenous language, Mayo, would be at risk within a trilingual context where both the majority language, Spanish, and a global language, English, were in play.

With regard to the role of English, applied linguists and sociolinguists have used predatory metaphors such as "killer language" (Pakir, 1991, cited in Mülhäusler, 1996) and "Tyrannosaurus rex" (Swales, 1997) to illustrate the dire consequences that proliferation of this "world language" (Kachru, 1992) has visited on people's local cultures, lives, and identities within a range of settings - from rural, indigenous villages in Papua New Guinea to technologically advanced societies such as Germany (Eckert et al., 2004). They argue (e.g., Phillipson, 2009) that English and other "killer languages" are learned subtractively at the cost of indigenous and other minority languages (Benson, 2009; Cummins, 2009; Skutnabb-Kangas, 2009) instead of additively, that is, in addition to the mother tongue. 
Lambert and Tucker (1972) first proposed the principles of additive and subtractive bilingualism to account for divergent findings of empirical studies that sought to evaluate the success of bilingual education programs introduced in North American classrooms in the 1970s and 1980s. For example, findings of a plethora of studies on students' bilingual language acquisition within (early total, early partial, and late partial) French immersion programs serving English-speaking Canadian student populations were, on the whole, highly positive (e.g., Swain \& Lapkin, 1982). On the other hand, evidence from studies of programs of English immersion for Hispanic immigrant children in the United States was not encouraging, pointing instead to the need for a policy of sustained heritage language education to avert assimilationist outcomes that would threaten academic literacy development in both the majority and minority varieties (Cummins, 1994). Several applied linguists go as far as to suggest that programs of multilingual education involving English in contexts where a minority language is at risk violate the United Nations Convention on the Rights of the Child (Article 29, UNICEF) and represent linguistic genocide (Skutnabb-Kangas, 2001). Endorsing a more moderate position, López (2008) highlighted the importance that English has in the agenda of IBE across the Americas while acknowledging the challenge that the inclusion of English poses in "the fact that in many communities children have lost active use of their ancestral language" (p. 142; cf. Cenoz, 2004).

In the end, such concerns are never entirely allayed through state-authored measures. A significant responsibility falls to educators, particularly language teachers, to straddle these tensions, including those heightened through changes in educational policy (e.g., Clemente, 2009; Varghese \& Stritikus, 2005), to negotiate a language pedagogy that averts attrition of a minority language while introducing a lingua franca that might prove useful to disenfranchised students in their future endeavours (Canagarajah, 1999; Kamwangamalu, 2005). In presenting our study's findings, we shall see how professional educators exercised their agency as stakeholders in a subaltern, indigenous context as they negotiated the tensions between the minority (Mayo), majority (Spanish), and global (English) varieties as they carried out their responsibilities as multilingual educators.

However, we would first acknowledge that teaching the minority language within a school curriculum does not in itself guarantee its maintenance (Ferguson, 2006; Fishman, 1991), and that language socialization practices at home and in the community also play significant roles in fostering or impeding conditions for dual language development (Schecter \& Bayley, 1997; Zentella, 1997). With regard to indigenous contexts, language socialization research within an ethnographic perspective has been used to address issues related to how modernity has affected the ways in which children are socialized in and through language and how these changes shape language shift and cultural reproduction (e.g., Kulick, 1992; Patrick, 2003). Studies of language socialization within linguistic minority households and communities have shown that bilingual home environments that maintain high levels of the minority language use are generally associated with additive bilingualism (Cha \& Goldenberg, 2015; Schecter \& Bayley, 1997), although we would offer a disclaimer that minority versus majority language use patterns in households tend to fluctuate over time and cannot be taken for granted over the long term. Findings from our own research (Schecter \& Bayley, 2002, 
2004) have confirmed the tenuous quality of valorization of specific language practices given the effects of modernization processes on community members and the fluidity of individuals' personal circumstances.

All to say, the ethnographic findings that we report here represent a portrait of a community at a given point in time. We understand that the ecology of this community is changing; indeed, it is already different (Barad, 2007).

\section{Research Context}

\subsection{The Sociolinguistic Canvas for Multilingual Education in Mexico}

In this section, we elaborate on the sociolinguistic landscape and infrastructural context for multilingual education in Mexico. Mexico was a multicultural and plurilingual territory even before the Spaniards colonized it in the 16th century; and yet it was only in 2003 that the country was officially acknowledged as a multilingual and multicultural nation through an amendment to the Constitution (Gutiérrez Estrada, 2015). Terborg, García Landa, and Moore (2006) report that at the time of colonization by Spain more than 100 indigenous languages and dialects were spoken throughout Mexico. After the conquest many indigenous languages perished; however, a significant number survived. While assessments are discrepant, the National Institute for Indigenous Languages (INALI) reports 68 indigenous languages currently in use (Puebla Online Noticias, 2014).

Ochoa Sandy (2009) reports that the major cause for the decrease in indigenous communities in the country is social marginalization. Others have documented processes of urbanization (Aguilar Zéleny, 1995) and poverty and discrimination that over the years have led to the degradation of Mexico's indigenous peoples and their assimilation to Mestizo culture (Díaz-Couder, 1998; Muñoz Cruz, 1998). In an effort to reverse the process of ethnocultural attrition (Edwards, 1994; Fishman, 1989), in 2003 the Mexican government passed the General Law of Linguistic Rights of the Indigenous Peoples, marking a shift from a policy of "bilingual education" to what is now referred to as Intercultural Bilingual Education (IBE). Previous attempts at what was termed bilingual education in Mexico were associated with processes of cultural and linguistic assimilation and claimed by linguists to represent integrationist models (Hamel, 2000; Muñoz Cruz, 1997, 1998; Terborg et al., 2006). However, in the last decade, this situation has changed as a consequence of the emergence of social and political movements in Mexico and in the world, notably the Zapatista Army of National Liberation.

In any case, over the past few years the above constitutional revisions have been implemented, and Intercultural Bilingual Education has been introduced across Mexico. The new policy specifies the duty of the government to promote the equitable and sustainable development of indigenous communities and Intercultural Bilingual Education (Schmelkes, 2005, p. 4). Consequently, at all levels of education in Mexico-elementary, secondary, postsecondary - it is required that attention be paid to the complex historic, socioeconomic, and linguistic contexts in which indigenous communities have developed and evolved. The revised constitution also adopts the principles and guidelines set up by UNESCO (2006) 
regarding recognition of linguistic and cultural diversity.

Thus, Intercultural Bilingual Education is based on the following principles: (a) respect for the cultural identity of the learner through the provision of culturally appropriate and responsive quality education for all; (b) access for learners to cultural knowledge, attitudes, and skills necessary to achieve full participation in society; and (c) respect, understanding, and solidarity among individuals, ethnic, social, cultural, and religious groups, and nations (UNESCO, 2006, pp. 33-38). These principles were subdivided into areas of concern for stakeholders (teachers, administrators, parents, community advocates), and pedagogic approaches that highlighted the cultural and linguistic heritages of minority groups were proposed, developed, and introduced into local educational landscapes.

However, skepticism towards intercultural education has been ongoing. Verma (1997) expressed the caveat that the goal of intercultural education should not focus solely on recognizing and appreciating cultural diversity in society, as this would constitute tokenism. Rather, the significance of a culture's history and tradition should be considered part of the dynamic and multifaceted culture of contemporary society (p. 63). Verma additionally proposed that, with regard to the development of curricula and pedagogies, it is important to "integrate an understanding of cultural process and cultural continuity and changes within a framework of national identity" (p. 64). Fishman (1994, as cited in Sepúlveda, 2002) cautioned that those spaces open to ethno-diversity will not stop tendencies towards globalization and assimilation, but held out hope that there could exist a symbiotic (as opposed to adversarial) relationship between a globalizing project and spaces of ethno-diversity.

\subsection{The Infrastructural Context for Multilingual Education in Seagulls}

The Office of Intercultural Bilingual Education (CGEIB) and other governmental and nongovernmental agencies share responsibility for creating, designing, and implementing programs of bilingual and multilingual education in the various jurisdictions. This task is daunting given the status of multiple indigenous languages in different regions of Mexico and the discrepant reports that produce uncertainty in planning around levels of bilingualism, numbers of speakers, and literacy types and levels within the different indigenous communities. In the case of the Mayo community of Seagulls, on the Sea of Cortez in the southwestern part of the state of Sonora, on the surface Mayo appeared to be taught as a second language within different households even before the formal implementation of IBE. That is, although a majority of parents spoke Mayo as their first language when they were growing up, they elected to speak primarily Spanish to their offspring. Indeed, Mayo appeared to enjoy the status of a heritage language within the community, that is, a non-majority language spoken by groups identified as linguistic minorities under specific circumstances (Valdés, 2005, p. 411). The children of Seagulls displayed some receptive ability in the Mayo language.

However, although the official policy mandated a curriculum of Intercultural Bilingual Education across all educational levels, in practice IBE is currently visible mainly at the elementary level. For indigenous communities, at the junior high school level one finds a 
variety of culture-themed classes, mandated and offered by each state government. These programs are delivered mostly in the form of telesecundarias (UNESCO, n.d.). In this program, students are given lessons through television and then undergo standardized tests to assess their content and linguistic mastery. Nevertheless, around the globe and in Mexico, a movement of IBE proponents is gathering that privileges "local needs, so that more realistic policies can be developed” (Terborg et al., 2006, p. 457).

An example of the gap between policy rhetoric and reality in the context of language programs in Mexico (Baldauf \& Kaplan, 2007) is the current Programa Nacional de Inglés (National Program of English), or PRONI. PRONI represents a national initiative whose goal is to implement English as a second language in public preschools, elementary schools, and secondary schools in Mexico. PRONI seeks to promote the teaching of English as an additional language beginning in the last year of preschool through junior high. It follows a series of international guidelines - those established by the Common European Framework of Reference for Languages: Learning, Teaching, Assessment (Council of Europe, Language Policy Unit, 2001) — and national standards, and has been implemented in several states.

This said, notwithstanding the revised mandate of PRONI, a state-funded program for English instruction was already simultaneously in place, the Programa de Inglés en Primaria (PIP), implemented in 1992. The PIP was initiated because of the interest of a group of parents in the state of Sonora in their children learning English. These parents requested that the Ministry of Education provide their children with an ELT program and offered to contribute funds to enable the initiation of such a program.

Our main purpose in providing the information in the preceding sections is not to foreshadow our ethnographic findings but rather to set them in relief against the macro-institutional context that made the implementation of a trilingual curriculum possible in the community of Seagulls. For while in the different areas that constitute IBE in Mexico we see evidence of the difficulties and caveats alluded to by scholars and other stakeholders we have cited in this paper, our work points in another direction-to the role of agentive practices and embodiment processes at the local level in counteracting, or at least limiting, the potentially harmful effects of such undermining forces.

\subsection{The Mayo People and Language}

The Mayo region is located in the northwest of Mexico, in southern Sonora and northern Sinaloa, towards the Pacific coast (see Figure 1). Mayo is spoken in more than 100 villages in those states. According to Campbell (1997), Mayo and Yaqui and the extinct Tehueco are three language varieties from the Cahitan branch and part of the Uto-Aztecan language family. While Mayo in Sonora and Mayo in Sinaloa recognize each other as part of the same community, they acknowledge that organizational characteristics, government, traditions, features of the linguistic variety, and relations to Mexican culture and governmental institutions differ in some aspects across state boundaries (Aguilar Zéleny, 1995, p. 84). 


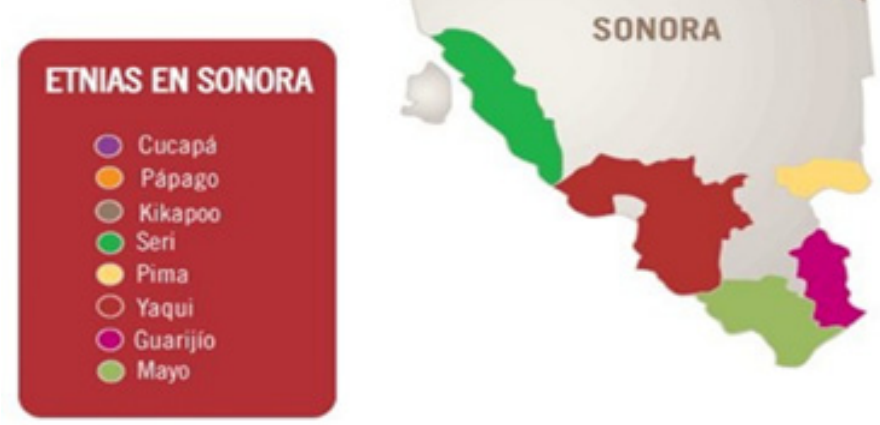

Figure 1. Indigenous groups in the State of Sonora, northwestern Mexico

Source: Instituto Nacional de Estadística y Geografía (INEGI). Retrieved from http://www.inegi.org.mx

\section{Methodology}

Paradigmatically, our study finds a home at the nexus of language policy and planning (LPP) and qualitative ${ }^{1}$ — specifically, ethnographic — research. Traditionally, LPP and ethnographic work would have been viewed as epistemologically divergent. Language policy and planning research tended to explore policy in a national or community context at the macro level (i.e., institutionally, from the top down), whereas ethnographic research is rooted in a community's viewpoint, taking into consideration the perspectives of all actors with claims to membership (i.e., bottom-up; see Hornberger, 1996).

However, recent work in LPP and ethnography has created space for a rapprochement with respect to this traditional dichotomy. The field of LPP now embraces and incorporates multiple epistemological perspectives, including those embedded within a postmodernist lens (Canagarajah, 1999; Mair, 2003; Pennycook, 2001; Ricento, 2000), as well as engaged language policy and practices (ELP) situated within critical ethnography (e.g., Davis, 2014; Newcomer \& Puzio, 2016; Schecter, García Parejo, Ambadiang, \& James, 2014). This study identifies with the perspective of engaged, activist LPP, where policy is not only codified in official, institutional texts but also simultaneously transformed and reconstituted through the actions of agentive individuals who are direct participants in the problems or processes being investigated (Schecter \& Ippolito, 2008) and in interaction with material and other forces on the ground (Kuby \& Rucker Gutshall, 2016).

For the purposes of this paper, we focus on the more comprehensive study's ethnographic findings related to the socially constructed meanings that stakeholders attach to the teaching of English and Mayo in this minority language setting (Merriam, 2002). Specifically, we address stakeholders' attitudes towards indigenous language maintenance as well as their 
stances regarding English language culture and the teaching and learning of English in a minority language setting.

\subsection{Procedures and Instrumentation}

\subsubsection{Research Site}

The field site for this study was Benito Juárez Intercultural School, a federally funded intercultural bilingual school located in the town of Seagulls by the Sea of Cortez in the southwestern part of the state of Sonora. The major economic activity in the town of Seagulls is fishing. Its population of approximately 8,000 people consists predominantly of indigenous Mayo. The school offers Grades 1 through 6 and a year of preschool. It also serves as a boarding school for children who live outside Seagulls. At the time the study took place, between 2008 and 2010, approximately 144 students attended the school; 50 of those were boarders. As for instructors, there were eight, three of whom self-reported as bilingual. The other instructors reported some knowledge of the Mayo language.

\subsubsection{Sampling and Participants}

For the purposes of this study we used criterion sampling (Ellsberg \& Heise, 2005), which allows in-depth investigation of a particular type of case by identifying sources of variation ( $\mathrm{p}$. 106). Primary participants were:

> Juan, trilingual teacher at Benito Juárez Intercultural School and, as vehicle for Intercultural Bilingual Education in Seagulls throughout 2008-10, our key informant;

$>$ Rosa, regional coordinator of the PIP. She is also an English instructor in the University of Sonora;

> María, principal of Benito Juárez School;

$>$ Ana, Grade 5 teacher and Juan's sister.

$>$ Additional participants were:

> 13 students in Juan's Grade 5 class and 20 students in his Grade 6 class (2008-09);

> 18 parents/primary caregivers, 9 of Grade 5 students and 9 of Grade 6 students;

$>$ A Mayo teacher from another town;

$>$ Laura, a research assistant.

\subsubsection{Data Collection}

The following sources of information were used to inform our ethnographic analysis:

Demographic data were collected to document focal children's ages, number and ages of siblings and other household residents, parental vocations, and language use at home. This information was collected through two questionnaires, one given to students in Grades 5 and 6 and the second to their parents. Participation was voluntary. 
Photographs of the linguistic landscape, including the community and school settings, were used to contextualize the research by facilitating a visual (and hence multimodal) appreciation of the study's physical environment.

Six interviews were conducted - three with the Mayo-English teacher, Juan; two with the principal of Benito Juárez School, María; and one with the regional coordinator of PIP, Rosa. Interviews, which followed a semi-structured format, were audiotaped. Protocols elicited participants' perspectives on a variety of topics, including: attitudes towards the Mayo language and cultural maintenance; views/values concerning importance of English, Mayo, and Spanish for/in school and in relation to future life opportunities; and respondents' views regarding current language and educational policies.

Participant observation at Benito Juárez Intercultural School, conducted by the first author, spanned a period of 2 years, beginning in 2008 and ending in 2010. The principal researcher travelled to the school once a month to observe 4 hours of classes monthly ( 2 hours for Grade 5, 2 hours for Grade 6). A 2-hour demo class taught by Juan in Mayo and English to the parents of children in both classes was also observed. ${ }^{2}$

Fieldnotes, taken by the first author and the project's research assistant, served to document events and activities that unfolded during the course of participant observation and constituted important vehicles for triangulation.

Questionnaires were administered to the children of the Mayo-English classes and their parents. The sample consisted of 29 students (11 from Grade 5 and 18 from Grade 6) and 18 parents (9 from each grade). Participation in this activity was voluntary. Questionnaire protocols were open-ended and focused on caregivers' and children's attitudes towards Mayo and English. ${ }^{3}$

An impromptu focus group meeting of approximately two and half hours with Juan, Ana, and another Mayo teacher from a neighboring town was organized on a day when classes were cancelled. Participating educators were engaged on a range of topics of particular interest to this study, including: Juan's class organization, with focus on uses of Mayo and English; participants' ideas about linguistic maintenance and the political climate within Mexico in which such efforts are embedded; and language loss and the impact of the death of community elders on cultural continuity in Seagulls.

\subsubsection{Data Analysis}

In carrying out these procedures, we were able to observe and construct an account of teachers' and students' daily activities in their Mayo and English classes, paying close attention to the roles that these languages played on a daily basis and to how these languages were negotiated within the classroom. Because an important dimension of ethnographic analysis involves acknowledging and privileging participants' "attitudes, beliefs, behaviors, and practices" (TESOL International Association, n.d.), we attempted to be especially sensitive to the nuances of participants' contributions, resisting reductive strategies whereby we would seek to encapsulate the emic perspective in a single expressed view volunteered at one point in time. We also paid attention to privileging the various voices struggling for 
legitimacy within the setting (Anderson, 1989, p. 261).

To prepare qualitative data for analysis, audio recordings of interviews and selected portions of instructional sessions were transcribed. Transcriptions and other data were organized into tentative categories based on themes that emerged inductively through a constant, recursive process (Bogdan \& Biklen, 2003) where we sought to both differentiate and combine the data we had assembled and our ongoing reflections on their significance (Miles \& Huberman, 1994, p. 56). Comparing and synthesizing data obtained through participant observation and interviews with those solicited for textual analyses (e.g., government position papers, instructional materials) ensured triangulation of our research findings by providing an additional comparative lens between the LPP macro-context and the micro-context of engaged LPP on the ground (Davis, 2014, Schecter et al., 2014).

\section{Language Policy and Planning on the Ground: Ethnographic Findings}

\subsection{Preparing the Groundwork for Multilingual Education in Seagulls}

Seagulls is a small rural town by the Sea of Cortez. Most homes lie beside dirt roads and are humble in appearance - single-storied, built out of concrete - as are many homes in Mexico. However, there is one street with opulent homes owned by people from the city, and a few other, less opulent homes owned by upper-middle-class people, are found within the town boundary along a paved road. The dirt road ends where these more endowed homes start.

In our interview with Rosa in 2008 (the regional coordinator of the PIP), she recounted how members of two communities located in rural areas had approached her office to request English classes for their children in the elementary and secondary schools. One of these communities, in Seagulls, educated primarily Mayo children. The immediate problem in Seagulls was that students in junior high school were failing their English subject class, delivered via telesecundarias. Therefore, community members were concerned that their children would be unable to attend high school elsewhere and required to remain in the town. Additionally, they viewed English as a symbolic and material resource (Bourdieu, 1977) that would provide their children with access to future opportunities such as employment, higher education, and upward social mobility.

While there was a clear investment (Norton, 2000) on the part of the Seagulls community in learning English, at the same time community members expressed a dedication and commitment to maintaining their heritage language, Mayo. This community commitment was uppermost in the minds of Rosa and the director of the PIP when they determined in a planning meeting in April 2005 that Mayo would be the primary language of instruction, even in the English classroom, and that educational materials to be used for delivering the curriculum would be in both Mayo and English "to reinforce the learning of the children's second language [in this case Mayo is considered the second language and Spanish the first]" (Minutes of discussion between Rosa and PIP director, April 27, 2005). With the support of members of the Seagulls community, Rosa and the director of the PIP went so far as to stipulate in the mandate of the new program that "if after initiating English classes, children prefer English to Mayo, the English classes will be stopped." 


\section{Macrothink $\Delta$ Institute ${ }^{\text {tm }}$}

In the same interview, Rosa also described the curriculum decisions that needed to be made to realize the dual language classes. In this regard, an important consideration was the likelihood (and difficulty) of finding a teacher who would enable a curriculum in both Mayo and English. Rosa explained:

Rosa, Regional Coordinator of the PIP: After meeting the parents and community of Seagulls, we came back [the Director of the PIP and Rosa] and discussed the importance of hiring a teacher with the "sensibility" of the three languages, being able to use them, a teacher who would need to have the "disposition" to only be paid 750 pesos a month per group ... and commute three times a week to teach two 50-minute classes. We also had to think of creating a program, so we asked the surrounding schools and other indigenous schools to give us their thematic outlines. (2008)

Indeed, identifying a qualified trilingual teacher proved a daunting challenge, and for the first year (2006) of the English program at Benito Juárez Intercultural School, a teacher who spoke only Spanish and English was hired. This situation did not facilitate the inclusion of the indigenous variety in the language curriculum although, as explained by the principal and various teacher colleagues, some efforts were made to incorporate Mayo into subject matter classes. In 2006, Rosa made the acquaintance of Juan (Figure 2), a trilingual (Mayo-Spanish-English) teacher working for the PIP program in another town. It was not until 2007 that Juan was able to take up the position of Grade 5 and 6 teacher at Benito Juárez Intercultural School in Seagulls.

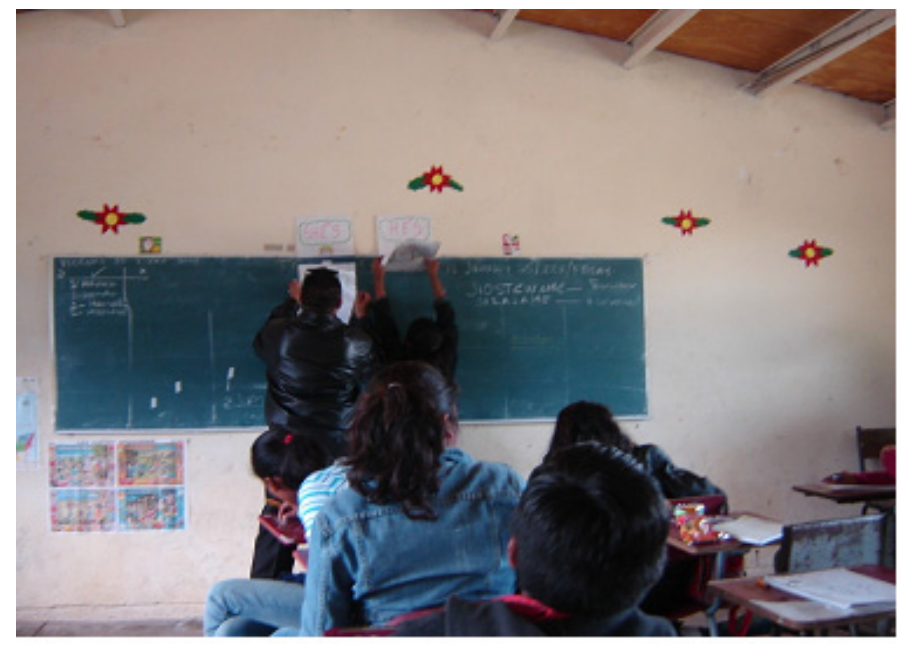

Figure 2. Juan and his students in class

\subsection{Participant Observation in Juan's Classroom}

On Rebeca's first visit to Juan's classroom, she noted that the lights were dim and the windows were covered with paint or newspaper to prevent the sunlight from getting inside because of the extreme heat. The state of Sonora is part of the Sonora-Arizona desert. In the late spring, 


\section{Macrothink}

summer, and early fall, in areas like Seagulls, although by the sea, the temperature is in the high 30s Celsius and often in the mid-40s. Therefore, classrooms are often darkened to keep them cooler.

Juan usually would make his own instructional materials. He made drawings as visuals for his classes - using magazine or newspaper cutouts, but mostly his own drawings. There were also drawings in the main cafeteria area that showed vocabulary in Mayo as shown in Figure 3. As part of the principal author's agreement with Juan and the principal, the teacher was provided with materials on different occasions throughout the fieldwork visits. Construction paper, markers, chalk, scissors, a used tape-CD recorder, several dictionaries, and books were furnished for the teacher to use.

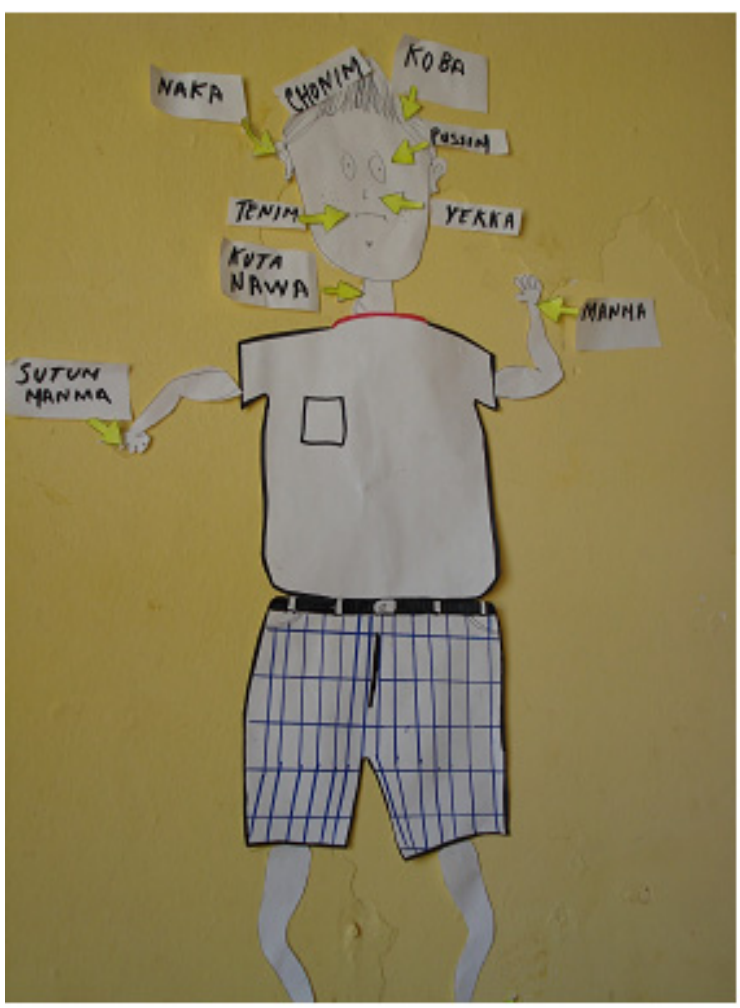

Figure 3. Some parts of the body in Mayo

The structure of Juan's class was the same over the 2-year span of the study; however, the duration of the class changed three times. When Juan began teaching at Benito Juárez Intercultural School, he taught the Grade 5 and 6 students 3 hours a week of language (Mayo and English); then later in 2009, the time for language instruction was reduced to 2 hours per week. In Rebeca's last visit in 2010, with the creation of PRONI, the group teacher would be in charge of Mayo and then Juan would be exclusively in charge of teaching English 2 hours per week. The group teacher would first give a lesson in Mayo and then Juan would mirror the exact same lesson in English. During the period of participant observation in the 2008-09 
school year, language instruction took place in three one-hour periods on Mondays, Wednesdays, and Fridays. The Grade 5 students would receive language instruction from 8 to 9 a.m., and the Grade 6 students from 9 to 10 a.m.

Juan would begin every class by reviewing content from the prior lesson. During these visits, he would alternate between placing Mayo and English at the beginning of his class. He used the same technique of drilling the vocabulary, having students repeat out loud, and providing games such as fill in the blanks with the correct word in Mayo or English. Juan showed us a program that people in the Office of Indigenous Education and the PIP had developed to follow the same curriculum for both languages. He did not have an actual textbook for Mayo for the Grade 5 and 6 students because, although books are free and, putatively, provided by the National Ministry of Education (SEP), they never actually arrived during the school year. Such conditions are common in rural areas throughout Mexico; indeed, in the 2 years that Rebeca was in contact with Juan, the children never received their books on time. However, this predicament did not deter Juan, as he would adapt curriculum from the Office of Indigenous Education and also materials from a textbook designed by a teacher of Mayo at the University of Sonora. During Rebeca's last interview with Juan in August 2010, he explained that he had been the one who adapted the English materials to be taught in Mayo:

Juan: It was my idea to think about how to do this, because I thought that for instance a student entering the classroom could greet us in English, but it would have to be the same for Mayo. (2010)

For English, the PIP used the book Bounce Now (Kniveton \& Llanas, 2010). During the time of the study, the Bounce Now textbook was being used by the PIP office in elementary schools throughout Sonora. An analysis of this particular textbook was not carried out, but we observed that Juan used it mainly as a source of in-class oral exercises for the students. The students rarely received homework for Mayo. However, the occasions when they did were significant in that these assignments required students to ask the elders of their family or community for clarifications, thus encouraging intergenerational sharing and transmission of knowledge about the heritage culture and language.

\subsection{Reclaiming a Shared Heritage: Strategic Negotiation and Reappropriation in the Language Classroom}

Noteworthy about Juan's classes is that the teacher, a trilingual speaker of Mayo, Spanish, and English, used the Mayo language throughout his lessons to convey curricular content and meaning. Juan explained:

Juan: These schools [indigenous schools] were founded so that the language would not be lost, this is something that I emphasize to the children a lot ... "let's help the Mayo language," we should feel sorry for it, they are languages and cultures that have always been there and they are tending to disappear. (2008)

The teacher further observed that the children were encouraged and motivated by his speaking Mayo to them even though many of them "only understand it, but they do not speak it." During our observations of Juan's classes, we gradually came to realize that the language 
alternation scenario promoted by Juan represented an elusive ideal in terms of an envisioned language maintenance strategy in minority language contexts. We also grew to appreciate the extent to which these seemingly effortless classroom scenarios represented a deep commitment on the part of the parents and school personnel to maintain the Mayo language and transmit it to their children. The following excerpt is taken from a focus group conversation where the group teacher (GT), Juan, and Rebeca discuss/debate the children's perceptions of and attitudes towards Mayo.

Group Teacher (GT): I was telling you that I think the children are embarrassed ... I think ... about learning Mayo ... What do you think?

Rebeca: ... I wanted to ask, if those children who speak it [Mayo] seem motivated.

Juan: The children no! They are not embarrassed!

GT: No?

Rebeca: But what is it that you say embarrasses them?

GT: ... They are embarrassed, I think, like them ... we carry the "stigma" that the person who speaks the Mayo dialect, right? That people will look down on them ... "You speak the dialect [Mayo], you are an Indian"

Juan: They discriminate against each other. They feel then ... they have this thing, they want to change, so I always tell the children, "Look kids, in these times a person who doesn't speak two languages is ... you have to know Spanish and also have mastery of English and of your native tongue that is the Mayo language right? ... Because I told the kids once, "If you understand Mayo, try to speak it, you'll learn English better" and then when I teach the indigenous language it seems like they are more willing ... 'cause I did tell them, "If you have mastery of the Mayo language, it will be easier for you to master English," and since then ...

\section{Rebeca: ... Were they more motivated?}

Juan: ... and that is why I try to introduce topics in both English and the dialect, for example I tell them "one, two, three" and we do an activity, sometimes I tell them "wepula, go'yi, babji.'." I think there are some children, who ... if we strengthen for instance Mayo more ... they are going to give more to it than to English, why? Because as you know ... that the only contact they have with English is through me...they don't have other relationships in English, they don't speak it or listen to it. However, with Mayo, for example if I give homework in Mayo, they immediately go and research with another person in the community, they talk to them and they begin to understand it [Mayo]. Why? Because Mayo is in their environment, they develop it and they are immersed in it, they are going to speak it. (focus group, 2008)

The above excerpt illustrates Juan's strategic manoeuvres in hedging his bets: If the students are not compelled by the case he makes for cultural and linguistic maintenance, he can always use the argument that practising Mayo will be helpful to them in learning English. In 
any case, his indefatigable commitment to minority language revitalization, as evidenced by the constant use of routines and drills in Mayo in his classes, cannot be disputed. Juan explained his perception that Mayo language loss was a relatively new phenomenon, since in his view people from his generation learned it well, whereas children nowadays do not want to speak the language and their only connection to the Mayo language and culture is through the elderly. Because of this heritage language attrition, he views motivating the students to learn Mayo as his main challenge, and principal mission, as a teacher. These excerpts, as well as Juan's and his colleagues' accounts of their experiences adapting their teaching situations and tools, show how language education policy is interpreted, negotiated, and rearticulated by key actors in the Seagulls community.

The teacher's proactive disposition towards fostering the symbiotic coexistence of the Mayo and English varieties can also be seen in a demo class (April 2009) that Juan prepared for the parents of his Grade 5 and 6 students. Bolstered by his principal's support, Juan went to considerable effort to prepare for this event-producing materials in Spanish, Mayo, and English and procuring refreshments that were served to parents and students.

In the demo class, Juan modelled his teaching techniques and the activities he would normally carry out with his Grade 5 and 6 students by eliciting parents' participation in several interactive exercises. The class started with an introduction to the class schedule for that day, followed by an activity that included greetings in both Mayo and English. This activity began with a child carrying out a sign with the greeting in Mayo on one side and the greeting in English on the other. Next, a parent volunteer did the same. Juan then asked the remaining participants to repeat this sequence. The overall tone of this event was uplifting - the children were thrilled to have their parents acknowledge their performances in the demo class - and visitors stayed afterwards to exchange with Juan about the pedagogic goals envisioned through the trilingual curriculum and their children's learning.

We note how, in this demo class for parents, as in Juan's regular classroom, the teacher went to some effort to ensure that there were no incidences where English displaced Mayo. Indeed, the two languages were distributed and honoured equally in Juan's classes. In this manner, the teacher demonstrated his respect for the aspirations and dispositions of community stakeholders regarding indigenous language maintenance and revitalization.

This said, we would be remiss if we did not underscore the challenges that Juan and María, the school principal, confronted in delivering a trilingual curriculum that was attentive to transmitting the Mayo community's linguistic and cultural heritage and respectful of its aspirations. Chief among these challenges was that the class teacher found little or no support at the meso-level for the school's instructional agenda. This predicament became exacerbated in the summer of 2010, towards the end of Rebeca's fieldwork, when Juan returned, frustrated, from a workshop hosted by PRONI. Apparently, government officials not acquainted with basic principles of language policy and planning had omitted certain elements from their PRONI workshop and on-site documents, as the emphasis in the workshop was entirely on English-only classrooms, with no mention of indigenous languages. Juan noted wryly: 
Juan: In the first level [referring to the PRONI content and workshop] it was suggested that we create an environment in the school and classroom of 100\% English. From the time when the child enters the school, for instance, the principal should greet the child in English. This is obviously funny. (2010)

Additionally, although the PRONI policy extensively cites CEFR, the Common European Framework of Reference for Languages (Council of Europe, Language Policy Unit, 2001), the program after which it was modelled, there were no references to multilingualism as a resource when programs for the teaching and learning of indigenous/minority languages were discussed at the workshop. Instead, workshop leaders placed the emphasis on the exclusive use of English in the classroom, conveying the clear message that in scenarios where Spanish is not the mother tongue, indigenous languages do not hold the same symbolic value as English.

\section{Discussion and Conclusion}

\subsection{Discussion of Study Findings}

While the findings from this ethnographic study are not intended to be generalizable, at the same time they provide insights into current educational scenarios and situations in diverse sociolinguistic contexts where endangered varieties come into contact with national and global varieties. In this section, we discuss the findings of this research endeavour in terms of these broader implications.

With regard to stakeholders' perspectives and attitudes towards minority language maintenance and the teaching and learning of English: we have seen how the majority of stakeholders were positively disposed to the curriculum and to educators attached to the teaching of English and Mayo at Benito Juárez Intercultural School and, moreover, were involved in various capacities with school-based policies and activities that encouraged heritage language maintenance and promoted the survival of Mayo culture. While motivation to receive instruction in English as an additional language existed on the part of caregivers from the start, we observed how, with the encouragement of the children's teachers, community members developed an increased appreciation and desire for their children to learn the Mayo language. Indeed, stakeholders came to look upon the children's acquisition of Mayo as an enrichment to their cultural resources and linguistic repertoires.

We also noted the efforts made at the micro level to ensure that indigenous children received the full advantage of exposure to Mayo and English in the language classroom, and we observed these efforts embodied in a committed language educator who on a daily basis enacted and rearticulated his pedagogical judgment (Todd, 2007) and disposition (Canagarajah, 2014) in promoting the simultaneous learning of Mayo and English. We have noted as well that such efforts were not free of the intricacies and complications resulting from inconsistencies, faulty logic, or paternalistic constructions contained in the current state policy regarding Intercultural Bilingual Education and the macro- and meso-level contexts of language policy and the educational system in Mexico. A lack of resources, late delivery of textbooks, class cancellations, insufficient teacher training, and poor labour conditions are just a few of the 
factors that committed teachers such as Juan had and still have to deal with on a regular basis. To overcome, or weather, these negative influences, both Juan and community members needed to work together towards the creation of symbolic and material resources that promoted the maintenance of the Mayo language as community cultural capital (Bourdieu, 1990, p. 19; Yosso, 2005) alongside English, a variety that represented a highly valued global commodity. This they did: We observed how Mayo and English were taught simultaneously and materials were devised despite the lack of funding and the absence of constancy in delivery of curricular materials.

Both Canagarajah (1999), and Kamwangamalu (2005), as postcolonial scholars, advocate that "what is needed and what should become the focus of [applied linguistics] research as it relates to postcolonial settings is to determine how English and local languages can coexist, not at the expense of the latter" (Kamwangamalu, 2005, p. 737). This position is evident in the pedagogy of Juan, who does not overtly resist English, but rather positions it at the service of the indigenous language, emphasizing that he values and favours the Mayo language and culture. In using English as a catalyst for heritage language revitalization and maintenance, Juan, as a minority educator, acts as an agent of transformative practice (Hornberger \& Johnson, 2007, p. 29) within the micro language planning context of IBE in Seagulls. We note, as well, in this study's findings how micro language policy and planning at the local level can go some distance towards counteracting the deleterious effects of inconsistent policy and planning on a macro level.

How do we reconcile our key informant's approach to multilingual pedagogy and the disjunctures between official language education policy and the realities and constraints associated with the resourcing of the language program at Benito Juárez Intercultural School? Clearly, Juan and his colleagues Rosa, coordinator of the PIP, and María, principal of the school, through their administrative platforms, addressed issues of language policy and planning by making agentive choices in particular situations, choices that were embodied in specific actions they initiated at both the classroom and community levels. On a daily basis, they made decisions about whether to take up the current policy as they understood it and implement it, or to contest the policy and attempt to reconstruct it.

Through our interviews and participant observation, we saw how educators can embody language maintenance (and loss) by investing themselves with the power and initiative to take up language education policy and transform it. All three key educators, Rosa, María, and Juan, facilitated and enabled changes towards the acquisition, maintenance, and transmission of Mayo in the community of Seagulls. In Juan's case, in particular, we observed this process of reembodiment in the enactment of a dynamic relationship between the teacher and the language curriculum, a relationship that involved advocacy that was reflective of the community's evolving stances with regard to issues of cultural maintenance and linguistic empowerment. Our findings illustrate how within a politicized reform context informed by global demands, professional educators can will themselves into a position to negotiate and navigate the tensions between the macro-level policies imposed by stakeholders at the national level and the meso-level policies that result from the interpretations of ill-informed bureaucrats at the jurisdictional level. 


\subsection{Theoretical Implications}

This study's findings have impelled us to reconsider earlier assumptions concerning the teaching of English as a second or foreign language in a subaltern, indigenous context. Over the course of the observations it became apparent that English was not positioned by stakeholders attached to Benito Juárez Intercultural School to play a role as "killer language" (Pakir, 1997), and that we would be well advised to reexamine our initial bias informed by the research literature on multilingual education in endangered language contexts. Although in the wake of globalization processes the spread of English is unavoidable and irrevocable, this study has shown that with careful planning and community consultation at the local level and a school-based commitment to support minority linguistic and cultural maintenance, the micro language policy context can be configured to promote a symbiotic relationship among the varieties, where one language supports and reinforces the other. And, while we abjure the imperialistic notion of English as a neutral language, at the same time as researchers and language educators we believe we might best serve those in whose interests we purport to work by considering ELT from a critical perspective that seeks "to reconstitute it in more inclusive, ethical, and democratic terms" (Canagarajah, 1999, p. 2).

Further, in light of our findings with regard to the relationship of Mayo and English within the context of this case study, it behooves us to revisit the theoretical binary additive and subtractive bilingualism, which has been in use in applied linguistics for nearly half a century. Indeed, the basic premise underlying this construct, that is, that the learning of a hegemonic variety will be at a "cost" (Baker, 2006) to the acquisition of the less influential language and therefore will impede learners' overall linguistic and cognitive development - did not hold up in the context of our study's findings. Rather, influenced by the perspective of Juan and María regarding the anticipated benefits of bilingual Mayo-English language development, residents of Seagulls grew to attach a positive association to simultaneous learning of Mayo and English, seeing this scenario as adding to their life opportunities.

\subsection{Implications for Research and Action}

Considerable work remains to be done with regard to the language revitalization of Mayo and other indigenous languages (Paulston, Chen, \& Connerty, 1993). In this regard, efforts on behalf of language revitalization and maintenance would benefit significantly from ethnographic research from a language socialization perspective (Ochs, 1988; Schecter \& Bayley, 2002; Schieffelin \& Ochs, 1986) that provides detailed accounts of how language varieties are experienced and used in family groupings and within social and community networks. With regard to indigenous multilingual contexts, Schecter (2015) has documented ways in which ethnography has been used "to address issues related to how modernity has affected the ways in which children are socialized in and through language and how these changes shape language shift and cultural reproduction, including literacy practices" (p. 199). In our view, this avenue of research is promising because the kind of information that researchers gather about students' lived realities, the linguistic resources to which they have access, and the relations among linguistic varieties in terms of who speaks what language to whom (Fishman, 1991) will assist educators in determining instructional approaches that will 
be most effective in their classrooms.

With regard to a plan of action, a process of engaged language planning and practice would see coordination of promotion of minority languages at the macro and micro levels as an important next step in positioning the indigenous variety as a resource that holds potential for the expression of a full spectrum of thought. In the case of Mayo, in 2009 the south campus of the University of Sonora experimented with teaching Mayo as an additional language to university students and faculty, a program that has continued until today. The Mayo instructor at the University of Sonora worked with Juan in preparing material that would support his teaching of the Mayo language. We see getting institutions such as universities to play an active role in creating symbolic and material resources to position minority languages on the same plane with other languages taught as an important strategy for promoting minority language learning and maintenance. The recognition by respected educators and intellectuals of minority languages alongside powerful global languages such as English sends a strong message to the effect that the indigenous language is an important national resource.

In addition, we encourage those working within teacher education circles to incorporate space within their teacher preparation programs and other institutional venues for minority language educators representing subaltern communities to become arbitrators of language policy (Baldauf, 2006; Sichra, 2006). In this manner, we promote community-referenced language policy and planning (Davis, 2014; Schecter et al., 2014) that facilitates the articulation and reframing of positions and perspectives on the part of important stakeholders such as teachers, caregivers (parents), and community elders. We see a process of engaged language planning and practice that unfolds at the grassroots, meso, and macro levels informing broader policy that addresses both the educational needs of indigenous people and the ways in which issues of identity and representation as contained in state-sponsored policy and curriculum impact demographic groups outside of indigenous communities - in Mexico, notably the Mestizo population.

Finally, it is time we accept the reality that English is viewed as a valuable commodity in many national, local, and glocal contexts, notwithstanding legitimate apprehensions. This condition serves as fertile ground for emergence of private "bilingual" schools to which the privileged send their children so that they will gain access to the language of power. However, with public education programs such as PRONI in place, English is now accessible to everyone. Therefore, discussions regarding pedagogical programs such as that established in the community school of Benito Juárez may productively address accessibility to linguistic and intercultural resources deemed of value in the broader society, taking into account issues of social justice surrounding language and the rights of minority communities. It's a tall order; but we know enough to proceed.

\section{References}

Aguilar Zéleny, A. S. (1995). Los Mayos. In Etnografia contemporánea de los pueblos indígenas de México: Región noroeste (pp. 83-130). México, D.F.: Instituto Nacional Indigenista. 
Anderson, G. L. (1989). Critical ethnography in education: Origins, current status, and new directions. Review of Educational Research, 59, 249-270. https://doi.org/10.3102/0034654 3059003249

Baker, C. (2006). Foundations of bilingual education and bilingualism (4th ed.). Clevedon, England: Multilingual Matters.

Baldauf, R. B. Jr. (2006). Rearticulating the case for micro language planning in a language ecology context. Current Issues in Language Planning, 7(2), 147-170. https://doi.org/ 10.2167/cilp092.0

Baldauf, R. B. Jr., \& Kaplan, R. (2007). Language planning and policy in Latin America: Vol. 1. Ecuador, Mexico and Paraguay. Clevedon, England: Multilingual Matters.

Barad, K. (2007). Meeting the universe halfway: Quantum physics and the entanglement of matter and meaning. Durham, NC: Duke University Press. https://doi.org/10.1215/ 9780822388128

Benson, C. (2009). Designing effective schooling in multilingual contexts: Going beyond bilingual models. In T. Skutnabb-Kangas, R. Phillipson, A.K. Mohanty, \& M. Panda (Eds.), Social justice through multilingual education (pp. 63-81). Clevedon, England: Multilingual Matters.

Bogdan, R., \& Biklen, S. K. (2003). Qualitative research for education: An introduction to theory and methods. Boston, MA: Allyn \& Bacon.

Bourdieu, P. (1977). Cultural reproduction and social reproduction. In I. Karabel \& A.H. Halsey (Eds.), Power and ideology in education (pp. 487-510). Oxford, England: Oxford University Press.

Bourdieu, P. (1990). The logic of practice. Stanford, CA: Stanford University Press.

Campbell, L. (1997). American Indian languages: The historical linguistics of Native America. New York, NY: Oxford University Press.

Canagarajah, A. S. (1999). Resisting linguistic imperialism in English teaching. Oxford, England: Oxford University Press.

Canagarajah, A. S. (2014). In search of a new paradigm for teaching English as an international language. TESOL Journal, 5(4), 767-785. https://doi.org/10.1002/tesj.166

Cenoz, J. (2004). Teaching English as a third language: The effect of attitudes and motivation. In C. Hoffmann \& J. Ytsma (Eds.), Trilingualism in family, school and community (pp. 202-218). Clevedon, England: Multilingual Matters.

Cha, K., \& Goldenberg, C. (2015). The complex relationship between bilingual home language input and kindergarten children's Spanish and English oral proficiencies. Journal of Educational Psychology, 107(4), 935-953. https://doi.org/10.1037/edu0000030

Clemente, A. (2009). Pedagogía crítica en el aprendizaje de lenguas en México. Imaginales: 
Revista de Investigación Social, 8, 11-32.

Council of Europe, Language Policy Unit. (2001). Common European Framework of Reference for Languages: Learning, teaching, assessment. Cambridge, England: Cambridge University Press. Retrieved June 25, 2017, from http://www.coe.int/t/dg4/linguistic/source/ framework_en.pdf

Creswell, J. (2007). Qualitative inquiry and research design: Choosing among five approaches (2nd ed.). Thousand Oaks, CA: Sage.

Creswell, J. (2009). Research design: Qualitative, quantitative, and mixed methods approaches. Los Angeles, CA: Sage.

Cummins, J. (1994). The acquisition of English as a second language. In K. Spangenberg-Urbschat \& R. Pritchard (Eds.), Kids come in all languages: Reading instructions for ESL students (pp. 36-62). Newark, DE: International Reading Association.

Cummins, J. (2009). Fundamental psychological and sociological principles underlying educational success for linguistic minority students. In T. Skutnabb-Kangas, R. Phillipson, A. K. Mohanty, \& M. Panda (Eds.), Social justice through multilingual education (pp. 19-35). Clevedon, England: Multilingual Matters.

Davis, K. A. (2014). Engaged language policy and practices. Language Policy, 13(2), 83-100. https://doi.org/10.1007/s10993-013-9296-5

Díaz-Couder, E. (1998). Diversidad cultural y educación en Iberoamérica. Madrid: Organización de Estados Iberoamericanos para la Educación, la Ciencia y la Cultura.

Eckert, T., Johann, A., Känzig, A., Küng, M., Müller, B., Schwald, C., \& Walder, L. (2004). Is English a "killer language"? The globalisation of a code. eHistLing, 1, 106-117.

Edwards, J. (1994). Multilingualism. London, England: Routledge. https://doi.org/10.4324/ 9780203430927

Ellsberg, M., \& Heise, L. (2005). Researching violence against women: A practical guide for researchers and activists. Washington, DC: World Health Organization/Program for Appropriate Technology in Health.

Ferguson, G. (2006). Language planning and education. Edinburgh, Scotland: Edinburgh University Press.

Fishman, J. (1989). Language and ethnicity in minority sociolinguistic perspective. Clevedon, England: Multilingual Matters.

Fishman, J. (1991). Reversing language shift: Theory and practice of assistance to threatened languages. Clevedon, England: Multilingual Matters.

Gaudet, S., \& Clément, R. (2005). Identity maintenance and loss: Concurrent processes among the Fransaskois. Canadian Journal of Behavioural Science, 37(2), 110-122. https://doi.org/10.1037/h0087249 


\section{Macrothink

Gutiérrez Estrada, M. R. (2015). Emergent identities and representations in ELT in minority language contexts in northern Mexico (Unpublished doctoral dissertation, York University, Toronto, Ontario).

Hamel, R. E. (2000). Políticas del lenguaje y estrategias culturales en la educación indígena. In Instituto Estatal de Educación Pública de Oaxaca (Ed.), Inclusión y diversidad: Discusiones recientes sobre la educación indígena en México (pp. 130-167). Oaxaca, Oax., Mexico: Instituto Estatal de Educación Pública de Oaxaca, Fondo Editorial de la Unidad de Proyectos Estratégico.

Hornberger, N. H. (1996). Indigenous literacies in the Americas: Language planning from the bottom up. Berlin, Germany, \& New York, NY: Mouton de Gruyter.

Hornberger, N. H., \& Johnson, D. C. (2007). Slicing the onion ethnographically: Layers and spaces in multilingual language education policy and practice. TESOL Quarterly, 41, 509-532. https://doi.org/10.1002/j.1545-7249.2007.tb00083.x

Instituto Nacional de Estadística y Geografía. (2008, August). Retrieved from http://www. inegi.org.mx

Kachru, B. B. (1992). World Englishes: Approaches, issues and resources. Language teaching, 25(01), 1-14. https://doi.org/10.1017/S0261444800006583

Kamwangamalu, N. M. (2005). Mother tongues and language planning in Africa. TESOL Quarterly, 39(4), 734-738. https://doi.org/10.2307/3588533

Kniveton, J., \& Llanas, A. (2010). Bounce now. México, D.F.: Macmillan Education Mexico.

Kuby, C. R., \& Rucker Gutshall, T. (2016). Go be a writer! Expanding the boundaries of literacy learning with children. New York: Teachers College Press.

Kulick, D. (1992). Language shift and cultural reproduction: Socialization, self, and syncretism in a Papuan New Guinean village. Cambridge, England: Cambridge University Press.

Lambert, W. E., \& Tucker, G. R. (1972). Bilingual education of children: The St. Lambert experience. Rowley, MA: Newbury House.

López, L. E. (2008). Indigenous contributions to an ecology of language learning in Latin America. In A. Creese, P. Martin, \& N. H. Hornbeger (Eds.), Encyclopedia of language and education: Vol. 9. Ecology of language (2nd ed., pp. 141-155). New York, NY: Springer.

Louis, W., \& Taylor, D. M. (2001). When the survival of language is at stake: The future of Inuttitut in arctic Québec. Journal of Language and Social Psychology, 20(1-2), 111-143. https://doi.org/10.1177/0261927X01020001006

Mair, C. (2003). Linguistics, literature and the postcolonial Englishes: An introduction. In C. Mair (Ed.), The politics of English as a world language: New horizons in postcolonial cultural studies (pp. ix-xxi). Amsterdam, Netherlands, \& New York, NY: Rodopi. 
Merriam, S. B. (Ed.). (2002). Qualitative research in practice: Examples for discussion and analysis. San Francisco, CA: Jossey-Bass.

Miles, M. B., \& Huberman, A. M. (1994). Qualitative data analysis: An expanded sourcebook. Thousand Oaks, CA: Sage.

Mühlhäusler, P. (1996). Linguistic ecology: Language change and linguistic imperialism in the Pacific Rim. London, England: Routledge. https://doi.org/10.4324/9780203211281

Muñoz Cruz, H. (1997). De proyecto a política de estado: La educación intercultural bilingüe en Bolivia, 1993. México, D.F.: UNICEF.

Muñoz Cruz, H. (1998). Los objetivos políticos y socioeconómicos de la educación intercultural bilingüe y los cambios que se necesitan en el currículo, en la enseñanza y en las escuelas indígenas. Revista Iberoamericana de Educación, 17, 31-50.

Newcomer, S. N., \& Puzio, K. (2016). Cultivando confianza: A bilingual community of practice negotiates restrictive language policies. International Journal of Bilingual Education and Bilingualism, 19(4), 347-369. https://doi.org/10.1080/13670050.2014.983043

Norton, B. (2000). Identity and language learning: Gender, ethnicity, and educational change. Harlow, England: Longman/Pearson.

Ochoa Sandy, G. (2009). Indicadores de cultura: La diversidad etnolingüística en México (primera parte). Este País Cultura, 24-25.

Ochs, E. (1988). Culture and language development: Language acquisition and language socialization in a Samoan village. Cambridge, England: Cambridge University Press.

Pakir, A. (1997). Education and invisible language planning: The case of the English language in Singapore. In J. Tan, S. Gopinathan, \& Ho Wah Kam (Eds.), Education in Singapore (pp. 57-74). Singapore: Prentice Hall.

Patrick, D. (2003). Language socialization and second language acquisition in a multilingual Arctic Quebec community. In R. Bayley \& S. R. Schecter (Eds.), Language socialization in bilingual and multilingual societies (pp. 165-181). Clevedon, England: Multilingual Matters.

Paulston, C. B., Chen, P., \& Connerty, M. (1993). Language regenesis: A conceptual overview of language revival, revitalization and reversal. Journal of Multilingual and Multicultural Development, 14(4), 275-286. https://doi.org/10.1080/01434632.1993.9994535

Pennycook, A. (2001). Critical applied linguistics: A critical introduction. Mahwah, NJ: Lawrence Erlbaum Associates.

Phillipson, R. (2009). English in globalisation, a lingua franca or a lingua frankensteinia? TESOL Quarterly, 43(2), 335-339. https://doi.org/10.1002/j.1545-7249.2009.tb00175.x

Puebla Online Noticias. (2014, February). Cuántas lenguas indígenas se hablan en México? Retrieved July 8, 2015, from http://pueblaonline.com.mx/portal/index.php/actualidad/cultura/ item/1841-cuantas-lenguas-indigenas-se-hablan-en-mexico 
Ricento, T. (Ed.). (2000). Ideology, politics, and language policies: Focus on English. Amsterdam \& Philadelphia: John Benjamins. https://doi.org/10.1075/impact.6

Schieffelin, B. B., \& Ochs, E. (1986). Language socialization. Annual Review of Anthropology, 15, 163-191. https://doi.org/10.1146/annurev.an.15.100186.001115

Schecter, S. R. (2015). Language, culture and identity. In F. Sharifian (Ed.), The Routledge handbook of language and culture (pp. 196-208). New York, NY: Routledge.

Schecter, S. R., \& Bayley, R. (1997). Language socialization practices and cultural identity: Case studies of Mexican-descent families in California and Texas. TESOL Quarterly, 31(3), 513-539. https://doi.org/10.2307/3587836

Schecter, S. R., \& Bayley, R. (2002). Language as cultural practice: Mexicanos en el norte. Mahwah, NJ: Lawrence Erlbaum Associates.

Schecter, S. R., \& Bayley, R. (2004). Language socialization in theory and practice. International Journal of Qualitative Studies in Education, 17(3), 605-625. https://doi.org/ 10.1080/0951839042000253621

Schecter, S. R., García Parejo, I., Ambadiang, T., \& James, C. E. (2014). Schooling transnational speakers of the societal language: Language variation policy-making in Madrid and Toronto. Language Policy, 13, 121-144. https://doi.org/10.1007/s10993-013-9310-y

Schecter, S. R., \& Ippolito, J. (2008). Parent involvement AS education: Activist research in multilingual and multicultural urban schools. Journal of Curriculum and Pedagogy, 5(1), 163-183. https://doi.org/10.1080/15505170.2008.10411693

Schmelkes, S. (2005). México: Educación intercultural bilingue destinada a pueblos indígenas. AULA intercultural: El portal de la educación intercultural. Retrieved June 25, 2017, from http://www.aulaintercultural.org/article.php3?id_article=973

Sepúlveda, S. (2002). Consulta nacional: Informe sobre el estado de conocimiento de la educación intercultural desde el enfoque antropológico. México, D.F.: Secretaría de Educación Pública, Coordinación General de Educación Intercultural y Bilingüe. Retrieved June 25, 2017, from http://eib.sep.gob.mx/dmodelos/estado_de_conocimiento.pdf

Sichra, I. (2006). Entre la realidad y el deseo: Enseñanza de la lengua indígena e interculturalidad. investigación sobre la enseñanza del quechua en colegios particulares en Cochabamba, Bolivia. Paper presented at the $52^{\text {nd }}$ International Congress of Americanists, Seville, Spain.

Skutnabb-Kangas, T. (2001). The globalisation of (educational) language rights. International Review of Education, 47(3), 201-219. https://doi.org/10.1023/A:1017989407027

Skutnabb-Kangas, T. (2009). Multilingual education for global justice: Issues, approaches, oppotrunities. In T. Skutnabb-Kangas, R. Phillipson, A. K. Mohanty, \& M. Panda (Eds.), Social justice through multilingual education (pp. 36-62). Clevedon, England: Multilingual Matters. https://doi.org/10.21832/9781847691910 


\section{Macrothink}

Swain, M., \& Lapkin, S. (1982). Evaluating bilingual education: A Canadian case study. Clevedon, England: Multilingual Matters.

Swales, J. M. (1997). English as Tyrannosaurus rex. World Englishes, 16(3), 373-382. https://doi.org/10.1111/1467-971X.00071

Terborg, R., García Landa, L., \& Moore, P. (2006). The language situation in Mexico. Current Issues in Language Planning, 7(4), 415-518. https://doi.org/10.2167/cilp109.0

TESOL International Association. (n.d.). Qualitative research: (Critical) ethnography guidelines. Retrieved June 25, 2017, from http://www.tesol.org/read-and-publish/journals/ tesol-quarterly/tesol-quarterly-research-guidelines/qualitative-research-(critical)-ethnography -guidelines

Todd, S. (2007). Teachers judging without scripts, or thinking cosmopolitan. Ethics and Education, 2(1), 25-38. https://doi.org/10.1080/17449640701302750

UNESCO (United Nations Educational, Scientific and Cultural Organization). (2006). UNESCO guidelines on intercultural education. Paris, France: Author.

UNESCO (United Nations Educational, Scientific and Cultural Organization). (n.d.) Abstract 8: Telesecundaria, Mexico (Lower secondary school learning with television support). Retrieved June 25, 2017, from http://www.unesco.org/education/educprog/lwf/doc/portfolio/ abstract8.htm

Valdés, G. (2005). Bilingualism, heritage language learners, and SLA research: Opportunities lost or seized? Modern Language Journal, 89(3), 410-426. https://doi.org/10.1111/ j.1540-4781.2005.00314.x

Varghese, M. M., \& Stritikus, T. (2005). "Nadie me dijo [Nobody told me]": Language policy negotiation and implications for teacher education. Journal of Teacher Education, 56(1), 73-87. https://doi.org/10.1177/0022487104272709

Verma, G. K. (1997). Inequality and intercultural education. In D. Woodrow, G. K. Verma, M. Rocha-Trindada, G. Campani, \& C. Bagley (Eds.), Intercultural education: Theories, policies and practice (pp. 55-76). Aldershot, England: Ashgate.

Yosso, T. (2005). Whose culture has capital? A critical race theory discussion of community cultural wealth. Race, Ethnicity, and Education, 8(1), 69-91. https://doi.org/10.1080/1361332 052000341006

Zentella, A. C. (1997). Growing up bilingual: Puerto Rican children in New York. Oxford, England: Blackwell.

\section{Notes}

Note 1. Creswell $(2007,2009)$ outlines the main characteristics of qualitative research: (a) it occurs in a natural setting; (b) the researcher acts as key instrument; (c) it has multiple 


\section{Macrothink}

sources of data; (d) data are analyzed inductively, i.e., researchers build their analysis from the bottom up; (e) it focuses on participants' meanings; (f) it has an emergent research design; (g) it uses a theoretical lens to analyze data; (h) it is interpretive; and finally (i) it contributes a holistic account of the context under study by providing multiple perspectives.

Note 2. We would offer one disclaimer here: Although we were told repeatedly by participants that Mayo was used throughout the different subject areas, since we observed only in Juan's classes we cannot resolve discrepancies in the information provided by the Grade 5 group teacher, the principal María, and the vice principal with regard to the school-wide usage of the indigenous language. As explanation we offer that language education policy for indigenous communities under the auspices of IBE is ambiguous and unclear. Moreover, most subject matter teachers are not professionally trained language educators, and no one in the school who worked as a full-time teacher felt confident in teaching the Mayo language. Most of these teachers were familiar with aspects of the heritage language, but not with the structure of the language or techniques for how to teach it. This scenario makes determination of whether or not the Mayo language is actually used in the curriculum outside of Juan's class difficult.

Note 3. Although we queried participants about their perceived proficiencies in Mayo in the questionnaire, the researchers did not ascertain proficiency levels of students in Juan's Grade 5 and 6 classes with regard to speaking, reading, and writing in Mayo.

\section{Copyright Disclaimer}

Copyright for this article is retained by the author(s), with first publication rights granted to the journal.

This is an open-access article distributed under the terms and conditions of the Creative Commons Attribution license (http://creativecommons.org/licenses/by/3.0/). 